\title{
Effects of 30-years of crop rotation and tillage on bacterial and archaeal ammonia oxidizers
}

J.W. Munroe, I. McCormick, W. Deen, and K.E. Dunfield

This is the peer reviewed version of the following article: Munroe, J.W., McCormick, I., Deen, W., \& Dunfield, K.E. Effects of 30-years of crop rotation and tillage on bacterial and archaeal ammonia oxidizers. J Environ Qual 45, 940-948 (2016). doi:10.2134/jeq2015.06.0331 which has been published in final form at https://doi.org/10.2134/jeq2017.08.0317. This article may be used for non-commercial purposes in accordance with Wiley Terms and Conditions for Use of Self-Archived Versions. 
Word Count including tables and figures (Excluding References): 7177

1. Present address: Jake Munroe, Ontario Ministry of Agriculture and Rural Affairs, 63 Lorne Ave. E, Suite 2B, Stratford, Ontario, Canada, N5A 6S4

2. Present address: Ian McCormick, FarmStart, 5420 Hwy 6 N., Guelph, Ontario, Canada, N1H $6 \mathrm{~J} 2$

3. Department of Plant Agriculture, University of Guelph, 50 Stone Road E., Guelph, Ontario, Canada, N1G 2W1

4. School of Environmental Sciences, University of Guelph, 50 Stone Road E., Guelph, Ontario, Canada, N1G 2W1

*author of correspondence:

K.E. Dunfield

Email: dunfield@uoguelph.ca

Phone: $519824-4120$ x 58088

Fax: 519 824-5730

Abbreviations: AOA, ammonia-oxidizing archaea; AOB, ammonia-oxidizing bacteria; qPCR, quantitative polymerase chain reaction; cDNA, complementary DNA; CC, continuous corn; RC, corn-corn-soy-wheat (red clover); NT, no-till; CT, conventional tillage

\section{Core Ideas}

- No-till showed trend of higher archaeal and AOA abundance across growing season

- Expression of archaeal amoA gene was undetected in our neutral pH agricultural soil

- AOA were, on average, more than 10-fold more abundant than AOB

- Abundance and gene expression of AOB, but not AOA, decreased with soil depth 


\section{Abstract}

32 Ammonia oxidizing bacteria $(\mathrm{AOB})$ and archaea (AOA) both mediate soil nitrification and may

33 have specialized niches in the soil. Little is understood of how these microorganisms are affected

34 by long-term crop rotation and tillage practices. In this study, we assessed abundance and gene expression of $\mathrm{AOB}$ and $\mathrm{AOA}$ under two contrasting crop rotations and tillage regimes at a 30-year old long-term experiment on a Canadian silt loam soil. Continuous corn (Zea mays L.; CC) was

37 compared with a rotation (RC) of corn, corn, soybean (Glycine max L.), winter wheat (Triticum aestivum L.) under-seeded with red clover (Trifolium pretense L.), with conventional tillage (CT)

39 and no-till (NT) as sub-plot treatments. Soil sampling was performed during the first corn year at 40 four time-points throughout the 2010 season and at three discrete depths $(0-5,5-15$, and $15-30 \mathrm{~cm})$.

41 Overall, AOA abundance was found to be more than $10 \times$ that of AOB, though AOA transcriptional 42 activity was below detectable levels across all treatments. Crop rotation had a marginally 43 significant effect on $\mathrm{AOB}$ abundance, with $1.3 \times$ as many gene copies under the simpler CC rotation 44 than the more diverse $\mathrm{RC}$ rotation. More pronounced effects of depth on AOB abundance and gene 45 expression were observed under NT versus CT management, and NT supported higher abundances 46 of total archaea and AOA than CT across the growing season. We suggest that AOB may be more 47 functionally important than AOA in this high-input agricultural soil, but that NT management can 48 promote enhanced soil archaeal populations. 


\section{Introduction}

Ammonia oxidation, the rate-limiting step in nitrification, was until recently believed to be

52 performed exclusively by autotrophic ammonia oxidizing bacteria (AOB). The discovery of

53 ammonia oxidizing archaea (AOA) (Venter et al., 2004; Treusch et al., 2005; Schleper, 2010) has

54 initiated a re-assessment of nitrification processes within a range of ecosystems. Given the impact

55 of nitrification on nitrate leaching potential and nitrous oxide production in agro-ecosystems, an

56 improved understanding of management effects on abundance and gene expression of ammonia

57 oxidation is needed. Quantitative molecular techniques have shown AOA to be abundant in soil

58 (He et al., 2007; Adair and Schwartz, 2008; Leininger et al., 2006; Prosser and Nicol, 2012).

59 However, in an agricultural soil, Jia and Conrad (2009) showed that despite greater abundance of

60 AOA, AOB were more active. Soil pH tends to influence AOA and AOB populations, where

61 increasing $\mathrm{pH}$ has been associated with increasing AOB activity (Nicol et al., 2008). Other

62 distinguishing physiological characteristics that may discriminate between AOA and AOB in

63 managed soil environments have been documented (Hatzenpichler, 2012; Prosser and Nicol,

64 2012). For example, $\mathrm{AOA}$ and $\mathrm{AOB}$ are believed to predominate in low and high ammonia soils,

65 respectively (Prosser and Nicol, 2012). Cultivated AOA have been found to have a higher substrate

66 affinity than AOB (Martens-Habbena et al., 2009), as well as a lower tolerance to ammonium

$67\left(\mathrm{NH}_{4}{ }^{+}\right)$levels (Hatzenpichler, 2012). Micro and mesocosm studies have demonstrated enhanced

68 growth and activity of AOB in soils amended with high levels of inorganic ammonium (Jia and

69 Conrad, 2009; Pratscher et al., 2011). Prosser and Nicol (2012) have proposed that ammonia status

70 of soils be considered on the basis of intermittent increases in concentration due to fertilization,

71 i.e. a high ammonia soil is one that recently received inorganic fertilization. Additionally, growth

72 of $\mathrm{AOA}$ has been linked to $\mathrm{NH}_{3}$ derived from organic materials, whereas $\mathrm{NH}_{3}$ from ammonium or 
73

74

75

76

77

78

79

80

81

82

83

84

85

86

87

88

89

90

91

92

93

94

95

urea fertilizers typically supports preferential growth of AOB over AOA (Hatzenpichler, 2012).

Stopnišek et al. (2010) and Levičnik-Höfferle et al. (2012) observed close interactions between soil organic $\mathrm{N}$ mineralizers and $\mathrm{AOA}$ in soil. Thus, the source of $\mathrm{NH}_{3}$, along with its concentration, is believed to govern niche adaptation of AOA and AOB.

Previous studies on AOA and AOB in agro-ecosystems have focused on long-term fertilizer amendments (Wessén et al., 2010; Zhang et al., 2012) and short-term responses to N inputs (Schauss et al., 2009), but little is known about the effects of crop rotation and tillage practices.

Quantification of gene and transcript abundance of AOA and AOB under various longterm crop rotation and tillage combinations can reflect how $\mathrm{N}$ is being transformed and complement information on pathways of potential $\mathrm{N}$ loss from the system. Soils managed under more complex crop rotations have been shown to have enhanced structural properties (Munkholm et al., 2013), which can lower risk of $\mathrm{N}$ losses by both nitrate leaching and nitrous oxide production. And though tillage practices have shown contradictory results with respect to emission of nitrous oxide, under best practices, no-till management have been shown to reduce nitrous oxide emissions (Wagner-Riddle et al., 2007).

Crop rotation is used to maintain soil fertility and to suppress pests (Davis et al., 2012). More diverse rotations have been found to increase yield and yield stability across a wide range of soil types and climatic conditions (Raimbault and Vyn, 1991; Légère et al., 2011; Davis et al., 2012; Munkholm et al., 2013; Gaudin et al., 2015). Soils under crop rotation tend to contain higher concentrations and qualities of soil organic matter, increased structural stability, increased quantities of microbial biomass and activities (Moore et al., 2000; Munkholm et al, 2013), and enhanced soil enzyme activities (Dick, 1992). Additionally, the inclusion of legumes in rotation, 
such as red clover, contribute $\mathrm{N}$ to the soil system and to the $\mathrm{N}$ requirements of the succeeding crop (Gaudin et al., 2013).

A majority of studies demonstrate higher soil microbial biomass under no-till versus conventional tillage systems (Wardle, 1995), which Kladivko (2001) attributes in part to cooler, wetter conditions and lesser fluctuations in temperature and moisture under no-till. Due to lack of soil disturbance, long term no-till management also results in stratification of organic carbon and N, (Edwards et al., 1992; Zibilske et al., 2002; Gál et al., 2007) but the impact that this may have on AO populations has not been investigated.

The objective of our study was to investigate the long-term effects (30 years) of tillage and rotation on the abundance and gene expression of AOA and AOB throughout a growing season. By contrasting a simple monoculture with a relatively complex rotation, and a strict no-till system with a conventional moldboard plow system, we intentionally sought to investigate magnified differences in management regimes. We hypothesized AOA to have a greater overall abundance under the more complex, legume-based rotation, due to a higher amount and diversity of plantderived organic N. Under no-till we predicted reduced AOB-to-AOA abundance and transcriptional activity with depth, in accordance with $\mathrm{N}$ stratification under such systems and respective affinities of each group for $\mathrm{NH}_{3}$. Finally, we hypothesized to observe increased abundance and gene expression of $\mathrm{AOB}$, but not $\mathrm{AOA}$, following an early season $\mathrm{N}$ fertilization event, regardless of tillage type or crop rotation.

\section{Materials and Methods}

\subsection{Site description and experimental design}

Samples were collected from the University of Guelph's Elora Research Station long-term rotation and tillage trial, established in 1980 and located in Elora, Ontario $\left(43^{\circ} 39^{\prime} \mathrm{N}, 8^{\circ} 25^{\prime} \mathrm{W}\right.$, 
elevation $376 \mathrm{~m}$ ). The soil on site is a well-drained Woolwich silt loam and classified as a Gray Brown Luvisol (CSSC, 1998) or Albic Luvisol (WRB, 2006). At 0-15 cm, soil texture was comprised of $29 \%$ sand, $52 \%$ silt, and $19 \%$ clay, organic carbon $26.9 \mathrm{~g} \mathrm{~kg}^{-1}$, and total $\mathrm{N} 2.4 \mathrm{~g} \mathrm{~kg}^{-}$ ${ }^{1}$ (Jayasundara et al., 2007). Soil pH range was $7.48-7.51$ (Table S1).

The experiment was designed as a randomized block split-plot with four replicates. The main plot treatment, crop rotation, included seven different rotation sequences. In this study, we collected data on two crop rotations: a corn (Zea mays L.) monoculture (CC), and corn-cornsoybean (Glycine max L.)-winter wheat (Triticum aestivum L.) with an under-sown red clover (Trifolium pretense L.) cover crop (RC). The red clover was frost-seeded into winter wheat in early spring and terminated in the fall after wheat harvest (by plowing in CT plots and by herbicide in NT plots). At the time of sampling, in 2010, both crop rotations were planted in their first year of corn. Plot treatment was tillage, and each rotation treatment included no-till (NT) and conventional tillage (CT), with mouldboard plowing to a depth of $15-20 \mathrm{~cm}$ as primary tillage under CT. Secondary tillage in CT plots involved two passes with a field cultivator and packer within 1 day of seeding. Fertilizer inputs were the same amongst all rotation and tillage treatments for corn and consisted of $157 \mathrm{~kg} \mathrm{ha}^{-1}$ of 5-20-20 (5\% N, 20\% $\mathrm{P}_{2} \mathrm{O}_{5}$, and $\left.20 \% \mathrm{~K}_{2} \mathrm{O}\right)$ applied at planting on May 7, 2010, and a second application of $150 \mathrm{~kg} \mathrm{~N} \mathrm{ha}^{-1}$ as urea-ammonium-nitrate (UAN; 28\% N) sidedressed in a band between corn rows on June 18, 2010. Nitrogen fertilization of other crops in the $\mathrm{RC}$ rotation is described in Jayasundara et al., 2007. Corn was harvested at full maturity on October 19, 2010 and yield was measured.

\subsection{Soil sample collection}

Soil sample collection dates were selected based on tillage and fertilization events. Samples were taken on May 3 (pre-cultivation and seeding, which occurred May 6 and 7, respectively), 
142 June 30 (post-nitrogen side-dress application of June 18), October 12 (pre-corn harvest and 143 plowing, which occurred October 18 and 19, respectively), and on November 23, 2010 (post-corn 144 harvest and plowing). Soil moisture and ambient air temperature values from each sampling date 145 are provided in Table S2. All samples were acquired using a $5 \mathrm{~cm}$ diameter soil core and were 146 separated at depth increments of 0-5 cm, 5-15 cm, and $15-30 \mathrm{~cm}$. Four subsamples per plot were

147 collected along a diagonal transect. Subsamples were separated by depth increment and 148 composited by plot. Nucleic acids were preserved in the field by placing two grams of fresh soil 149 from each collected sample immediately into $5 \mathrm{~mL}$ of Lifeguard Soil Preservation Solution 150 (MoBio Laboratories, Inc. Carlsbad, CA). Remaining soil was stored at $-20^{\circ} \mathrm{C}$ for nutrient 151 analyses.

\section{$152 \quad 2.3$ Nucleic acid extraction and reverse transcription}

153 Nucleic acids were extracted within 30 days of sampling, as described in Nemeth et al.,

154 2013. Total RNA and DNA were extracted from soils according to manufacturer's protocol using 155 the RNA PowerSoil ${ }^{\circledR}$ Total RNA Isolation Kit and DNA Elution Accessory Kit (MoBio 156 Laboratories, Inc. Carlsbad, CA). Both RNA and DNA were eluted using RNase and DNase-free 157 water. DNA concentration and purity was checked using NanoDrop 8000 spectrophotometry 158 (NanoDrop Technologies, Wilmington, DE). Isolated DNA was stored at $-80^{\circ} \mathrm{C}$. Isolated RNA 159 was immediately converted to complementary DNA (cDNA) via a reverse transcription reaction 160 (Promega, Madison, WI). Ten $\mu \mathrm{L}$ of RNA was used per reaction, which contained random primers 161 and the reverse transcriptase enzyme. Conversions were performed in triplicate for each sample. 162 A control reaction was performed using nuclease-free water instead of reverse transcriptase to 163 verify the absence of DNA. cDNA was stored at $-80^{\circ} \mathrm{C}$ until further analysis. 


\subsection{Quantitative analysis of genes and transcripts}

A quantitative polymerase chain reaction assay (qPCR) was performed to estimate abundance of $\mathrm{AOB}, \mathrm{AOA}$, total bacterial and total archaeal DNA and their respective transcripts. Primer pairs that target a segment of amoA (bacterial amoA), crenamoA (archaeal amoA), bac16S (bacterial), and $\operatorname{arch} 16 S$ (archaeal) genes were used, respectively (Rotthauwe et al., 1997; Tourna et al., 2008; Fierer et al., 2005; Kemnitz et al., 2007). Primer sequences can be found in Table S3. All qPCR assays were performed with a Bio-Rad iQ5 detection system (Bio-Rad Laboratories, Mississauga, ON). Optimized cycling profiles were used from the aforementioned citations, with the exception of $a m o A$, for which the thermocycle profile included an annealing temperature of 57 ${ }^{\circ} \mathrm{C}$ and was adapted from Glaser et al. (2010), and bacl6S, which was altered from Fierer et al. (2005) to 5 minutes at $95^{\circ} \mathrm{C}$, followed by 30 cycles of $94^{\circ} \mathrm{C}$ for 30 seconds, $55^{\circ} \mathrm{C}$ for 30 seconds, and $72{ }^{\circ} \mathrm{C}$ for 30 seconds, and a final 10 minutes at $72{ }^{\circ} \mathrm{C}$.

DNA extracts were tested for inhibition by dilution and appropriate dilutions were used for quantitative PCR. For each $1 \mu \mathrm{L}$ template (approx. $5 \mathrm{ng}$ of DNA, $1.5 \mathrm{ng}$ cDNA), reactions were performed in a total volume of $25 \mu \mathrm{L}$ per sample, with $12.5 \mu \mathrm{L}$ of $2 x$ SYBR Green Supermix, $10 \mu \mathrm{M}\left(10 \mathrm{pmol} \mu \mathrm{L}^{-1}\right)$ each forward and reverse primers, $1 \mu \mathrm{L}$ T4g32, and RNase and DNase free water. To reduce inhibitory effects of soil humic acid during the qPCR process, $150 \mathrm{ng} \mu \mathrm{L}^{-1} \mathrm{~T} 4$ gene 32 protein (Applied Biosystems, Life Technologies Corp., Carlsbad, CA, USA) was included (Kreader, 1996). Gene copy quantification was determined by fluorescence intensity of SYBR Green dye. Melt curve analyses were performed for each respective gene to verify amplicon specificity. Polymerase chain reaction runs had average efficiencies of 90.5, 89.4, 105.9, 94.2\% and average $\mathrm{R}^{2}$ values of $0.995,0.990,0.996$, and 0.996 for bacterial and archaeal amoA, and bacterial and archaeal $16 S$ genes, respectively. Each measurement was performed in triplicate and 
no-template controls in each run had undetectable amplification.

Serial dilutions of non-linearized plasmid DNA containing the target genes were used to construct standard curves. PCR products of bacterial and archaeal amoA and $16 S$ genes were cloned into One Shot ${ }^{\circledR}$ Top10 Escherichia coli competent cells using TOPO TA cloning kits (Invitrogen, Carlsbad, CA) according to the manufacturer's protocol. Products were amplified using plasmid specific primers, visualized by gel electrophoresis, and sequenced to verify the correct and complete sequence (Laboratory Services Department at the University of Guelph).

\subsection{Nutrient analyses}

Inorganic nitrogen was extracted from soil samples using $2 \mathrm{M} \mathrm{KCl}$. Extracted nitrate $\left(\mathrm{NO}_{3}{ }^{-}\right.$ -N) and ammonium $\left(\mathrm{NH}_{4}{ }^{+}-\mathrm{N}\right)$ concentrations were determined colourimetrically via segmented flow analysis (AutoAnalyzer-3, Seal Analytical, Mequon, WI) according to methods described in Drury et al., 1991 and converted to $\mathrm{mg} \mathrm{kg}^{-1}$ dry soil.

\subsection{Statistical analyses}

Data was analyzed using Statistical Analysis Software for Windows version 9.2 (SAS Institute, Cary, NC). Statistical differences were determined amongst and between different treatments, sample times, and sample depths. All data were analyzed in a generalized linear mixed model (Proc GLIMMIX). Data were adjusted with a natural logarithm transformation and analyzed with a normal distribution assumption. Sample time, as well as block and block interactions were set as random variables. Independent and interactive fixed effects were analyzed for crop rotation, tillage, sample time, and soil depth. Statistical significance was accepted at $P<0.05$, and $\mathrm{P}$-values $<0.10$ were considered marginally significant. Multiple means comparisons of gene counts were analyzed by least square means, using a Tukey adjustment $(\alpha=0.05)$. Due to missing data for bacterial amoA transcripts, data from depth increments of 0-5 and 5-15 cm, not $15-30 \mathrm{~cm}$, were 
analyzed to determine statistically significant differences amongst sampling dates. Treatment means and standard errors presented in figures were determined using non-transformed data.

\section{Results}

\subsection{Rotation effects}

Crop rotation did not affect AOA abundance, but did have a marginally significant effect on AOB abundance (Fig. 1). The CC rotation had a larger AOB community $\left(3.1 \times 10^{6}\right.$ gene copies $\mathrm{g}^{-1}$ dry soil) than the $\mathrm{RC}$ rotation $\left(2.3 \times 10^{6}\right.$ gene copies $\mathrm{g}^{-1}$ dry soil $)$ (Fig. $\left.1 \mathrm{a} ; P=0.06\right)$. When bacterial amoA gene abundance was normalized by bacterial $16 S$ gene abundance, the rotation effect was significant $(P=0.03$; Table $\mathrm{S} 4)$. The $\mathrm{CC}$ and $\mathrm{RC}$ rotations did not differ for AOA, with $6.1 \times 10^{7}$ and $6.5 \times 10^{7}$ archaeal $a m o A$ gene copies $\mathrm{g}^{-1}$ dry soil, respectively. A difference was not detected in mean bacterial amoA gene expression levels, which were $1.3 \times 10^{4}$ and $1.8 \times 10^{4}$ gene copies $\mathrm{g}^{-1}$ dry soil for $\mathrm{CC}$ and $\mathrm{RC}$ rotations, respectively (Fig. 1c). No archaeal amoA gene expression was detected in any samples.

\subsection{Tillage and depth effects}

Bacterial and archaeal amoA gene abundance overall were unaffected by tillage. The same was true for total bacteria and archaea (Table S4). Bacterial amoA transcript abundance, however, were significantly higher under no-till than conventional tillage ( $\mathrm{P}=0.05$; Table $\mathrm{S} 4)$. Community size of $\mathrm{AOA}$ and $\mathrm{AOB}$, as well as gene expression of $\mathrm{AOB}$, varied by depth according to tillage treatment when pooled by rotation and sampling dates. Under no-till, bacterial amoA gene abundance was significantly lower at $15-30 \mathrm{~cm}$ depth than at 0-5 and 5-15 $\mathrm{cm}$ (Fig. $2 \mathrm{a} ; \mathrm{P}<0.01$ for both). Similarly, mean bacterial amoA transcript levels under no-till decreased with depth, with a higher mean value at $0-5 \mathrm{~cm}$ than $15-30 \mathrm{~cm}$ depth (Fig. $2 \mathrm{c} ; \mathrm{P}=0.002$ ). No statistically significant differences existed, however, amongst depth increments for bacterial amoA gene abundance or expression under conventional tillage. Abundance of AOA, alternatively, was found to increase 
234 with depth, exclusively under conventional tillage. Mean archaeal amoA gene copy number was

235 greater at $15-30 \mathrm{~cm}$ depth than $0-5 \mathrm{~cm}$ (Fig. 2b; $\mathrm{P}=0.05)$. Statistically significant differences in

236 archaeal amoA gene abundance amongst depth categories did not exist under no-till.

237

238

239

240

241

242

243

244

245

246

247

248

249

250

251

252

253

254

255

256

\subsection{Tillage and seasonal effects}

Total bacterial and archaeal populations decreased during the 2010 growing season up until October 12 under both no-till and conventional tillage (Fig. 3a \& b). The archaeal population rebounded at the November 23 (Post-Plow) time-point, while overall bacterial abundance at November 23 did not differ significant from the previous two time-points. Total bacterial abundance at May 3 under no-till and conventional tillage was significantly greater than June 30 no-till $(P=0.02$ and 0.01 , respectively) and October 12 no-till $(P=0.02$ and 0.04 , respectively).

Total archaeal abundance was significantly greater at May 3 (no-till and conventional tillage) and November 23 under no-till than conventional tillage on June $30(P=0.01,0.01$ and 0.02 , respectively). Archaea showed a trend of greater abundance under no-till than conventional tillage management at all four sampling dates (Fig. 3b).

Ammonia oxidizing bacteria population levels rose slightly from May 3 to June 30, dropped substantially at October 12, and rebounded slightly at November 23 (Fig. 3c). Mean AOB abundance on October 12 under NT was significantly lower than that of May $3(P<0.0001)$, November $23(P=0.01)$, and June $30(P=0.01)$. When bacterial amoA was normalized to bacterial $16 S$ gene abundance June 30 abundance was marginally $(P=0.05$; Table $S 4)$ greater than that of May 3. No statistically significant differences existed between tillage types at any time-point for AOB. There were no statistically significant differences between sampling dates for bacterial amoA transcript levels (Table S4), likely due to large variability of data. Ammonia oxidizing archaea showed a similar pattern to that of total archaea throughout the season: abundance dropped 
257 from May 3 to October 12, but partially rebounded at the November 23 time-point (Fig. 3d). No 258 statistically significant differences existed amongst time-points for AOA; however, when 259 normalized by archaeal $16 S$, mean abundance on June 30 differed significantly from May $3(P=$ 260 0.02). Again, AOA showed a trend of greater abundance under no-till than conventional tillage 261 management at all four sampling dates (Fig. 3d), though there were no statistically significant 262 differences in mean AOA abundance at individual time-points between tillage types. 3.4 Soil nutrient concentrations

Mean soil ammonium and nitrate concentrations did not differ significantly by rotation or 265 tillage type (data not shown). Nitrate-nitrogen, but not ammonium, varied significantly amongst sampling dates when averaged across rotation, crop rotation, and tillage (Table S5). The June 30 267 sampling date had a $\mathrm{NO}_{3}{ }^{-}$concentration that was more than 2-3x greater than all other sampling dates: May $3(P=0.04)$; October $12(P=0.01)$; and November $23(P=0.01)$. Both Pre-Tillage

269 (May 3) and Pre-Plow (October 12) $\mathrm{NO}_{3}{ }^{-}$mean concentrations were greater than that of November $27023(P=0.01$ and 0.02 , respectively; Table S5).

\section{4. Discussion}

\subsection{Evidence of niche specialization between ammonia oxidizing bacteria and archaea}

As has been the case in many other studies on agricultural soils (Leininger et al., 2006; He

274 et al., 2007; Jia and Conrad, 2009; Wessén et al., 2010), we found AOA to be more than 10-fold 275 as abundant as AOB. Despite this finding, archaeal amoA transcripts were not detectable. AOB 276 transcripts, however, were detected in all samples, and found to largely mirror AOB abundance. It 277 is important to note that the analysis for AOA and AOB was performed on the identical cDNA 278 samples, therefore, we are confident that the lack of AOA gene expression was not an artifact of 279 PCR inhibition. It could be possible that the primers designed by Tourna et al. 2008 target a sub- 
population of AOA that are not active under our soil conditions. Overall, our results suggest that despite a substantial AOA population, AOBs were more transcriptionally active in this slightly basic, intensively managed agricultural soil. Jia and Conrad (2009) determined ammonia oxidation to be explained by $\mathrm{AOB}$ rather than $\mathrm{AOA}$ in a neutral $\mathrm{pH}$ agricultural soil upon addition of fertilizer $\mathrm{NH}_{4}{ }^{+}$, despite larger AOA populations. Nicol et al. (2008) observed decreasing AOA and increasing $\mathrm{AOB}$ transcriptional activity with increasing $\mathrm{pH}$ along a gradient of seven soils. Additionally, changes in nitrification rates in their study were most closely related to AOB gene abundance and expression across all soils (Nicol et al., 2008). However, both archaeal amoA gene and transcript abundance was greater than that of bacterial amoA in all soils studied (Nicol et al., 2008). In contrast, Gubry-Rangin et al. (2010) found a significant positive relationship between nitrification rate and growth of $\mathrm{AOA}$, but not $\mathrm{AOB}$, in a microcosm study in two acidic agricultural soils.

The absence of detectable archaeal amoA transcripts suggests that that AOA existed in the soil in high numbers, but were not actively oxidizing ammonia. This finding contrasts that of Leininger et al. (2006), who detected levels of archaeal amoA gene expression to be greater than or equivalent to those of $\mathrm{AOB}$ across three different soils. Interestingly, these particular soils were grassland pasture land, not soil under annual crop cultivation (Leininger et al., 2006). In our annual crop rotation, high input agricultural soil, AOA may utilize alternative energy acquisition strategies aside from ammonia oxidiation. Genes indicative of mixotrophy have been identified in several ammonia oxidizing archaea (Hatzenpichler, 2012). A high nitrogen-input soil environment, such as the one in our study, is likely one in which AOA were less competitive than AOB for ammonia substrate, given the preference of $\mathrm{AOA}$ for low $\mathrm{NH}_{4}{ }^{+}$concentrations (Hatzenpichler, 2012). Offre et al. (2009) determined that ammonia oxidation by archaea was more 
important than that of AOB in a microcosm study without external nitrogen input. Indeed, this may

304 be the case for soils in which the nitrification process is fuelled solely by continuous $\mathrm{N}$ 305 mineralization of soil organic matter; however, our agricultural soil had a high nitrogen input. 306 Additionally, nitrification has been shown to be governed primarily by AOA under acidic soil 307 conditions, whereas neutral and alkaline soils tend be dominated by AOB (Jia and Conrad, 2009; 308 Gubry-Rangin et al., 2010; Shen et al., 2012). Bacterial and archaeal ammonia oxidizer abundance varied substantially in relation to soil 310 depth and these distributions were affected differently by tillage for each group. In general, AOB 311 abundance and gene expression decreased from 0-30 cm depth, while AOA abundance increased. 312 This finding is similar to that of Leininger et al. (2006), who observed decreasing AOB and 313 constant AOA gene copy numbers with depth, in both fertilized and unfertilized agricultural soils. 314 Hatzenpichler (2012) also state that archaeal: bacterial amoA ratios increase with soil depth. Di et 315 al. (2010) found AOB abundance to decrease with soil depth in a grazed pasture soil, and attributed 316 the phenomenon to higher levels of nitrogen input to the topsoil. They observed a larger archaeal 317 than bacterial ammonia oxidizer community in the subsoil, which was explained as a consequence 318 of decreased $\mathrm{N}$ concentrations at lower depths (Di et al., 2010; Hatzenpichler, 2012). Indeed, our 319 data also show decreased N (data not shown), and decreased AOBs, lower in the profile. The fact 320 that ammonia oxidation alone does not sustain AOA growth (Tourna et al., 2008; Wessén et al., 321 2010), may also explain differences in relative AOA and AOB population levels at lower, more 322 oligotrophic soil depths.

We observed a significant decrease in AOB abundance and gene expression with depth 324 under no-till management, but not under conventional tillage. Stratification of total nitrogen and 325 organic carbon in the top $30 \mathrm{~cm}$ is a well-established phenomenon under no-till (Gál et al., 2007; 
326 Dimassi et al., 2013). Although we did not measure total nitrogen, our findings may reflect the 327 magnified stratification of $\mathrm{N}$ that commonly occurs under long-term no-till. In contrast, AOA 328 abundance did not change with depth under no-till, and in fact increased with depth under 329 conventional tillage. These patterns, both overall and in terms of individual tillage systems, suggest niche differentiation between AOA and AOB.

\subsection{Management effects on ammonia oxidizing bacteria and archaea}

When averaged across depths, sampling dates, and tillage treatments, we hypothesized that the $\mathrm{RC}$ rotation would support a larger AOA population than the $\mathrm{CC}$ rotation. Growth of AOA is associated with continuous low-level ammonia supply via organic matter mineralization (Offre et al., 2009), which we predicted to be enhanced following a red clover cover crop. The data, 336 however, did not show any difference between the contrasting rotations for AOA. Instead, AOB 337 abundance, when quantified relative to total bacteria, was found to be greater under the CC 338 rotation. Differences in soil mineral $\mathrm{N}$ concentrations in the season of sampling did not explain this phenomenon. Fertilization history of the two crop rotation treatments may have played a role. AOB are known to be well adapted to conditions common to cultivated soils (Zeglin et al., 2011), which include regular disturbance, influxes of inorganic $\mathrm{N}$ fertilizer, and high availability of $\mathrm{N}$ in soil (Cavagnaro et al., 2008). Since the establishment of the experiment in 1980, fertilizer $\mathrm{N}$ has

343 been applied according to general yield goal recommendations for the region (Raimbault and Vyn, 344 1991; Jayasundara et al., 2007). As a consequence of a higher frequency of corn, a high N345 demanding crop, the CC rotation received an average of 640-680 kg fertilizer $\mathrm{N} \mathrm{ha}^{-1}$ per four year 346 cycle, while the RC rotation received an average of only 410-430 kg fertilizer $\mathrm{N} \mathrm{ha}^{-1}$ per four year 347 cycle. Specifically, growth of bacterial but not archaeal ammonia oxidizers is associated with nitrification activity after high levels of ammonium input (Di et al., 2009; Jia and Conrad, 2009; 
349 Verhamme et al., 2011). It is possible that after 30 years of receiving an extra $60 \mathrm{~kg} \mathrm{ha}^{-1} \mathrm{~N}$ annually, 350 the $\mathrm{CC}$ rotation may have selected for $\mathrm{AOBs}$ compared to the $\mathrm{RC}$ rotation. Alternatively, 351 differences in crop residue and root composition between crop rotation treatments, in particular C:

$352 \mathrm{~N}$ ratios, are another potential driver of AOB abundance. Interestingly, at all sampling dates we observed a trend towards higher total archaeal 354 abundance under no-till management. This pattern existed for AOA as well, but was not observed 355 for total bacteria or the AOB community. Most organisms have a greater abundance under no-till 356 management than conventional tillage (Kladivko, 2001), although this is not true in all cases. For 357 example, abundance of Astigmatid mites has been shown to be negatively affected by tillage in 358 just under $50 \%$ of studies, while over $50 \%$ show minimal to large increases in abundance under 359 tillage (Wardle, 1995). However, in the majority of cases bacteria and fungi are negatively affected 360 by tillage in agro-ecosystems (Wardle, 1995). Relatively little is known regarding the effects of 361 tillage on archaea; the same is true for ammonia oxidizing archaea. Organisms from the 362 Thaumarchaeota phylum, to which AOA belong, were found by Dorr de Quadros et al. (2012) to 363 be more abundant under long-term no-till than conventional tillage management. Souza et al. 364 (2013) observed consistently higher archaeal abundance under no-till versus conventionally tilled 365 fields under a 13-year experiment - as determined by a shotgun sequencing approach - and 366 proposed archaea to be strong indicators of soil quality. Our results provide further indication that 367 no-till management promotes enhanced abundance of archaea, and suggest that AOA community 368 size may increase in response to reduced tillage.

AOB population sizes are known to increase in response to nitrogen fertilization in 370 agricultural soils (Hermansson and Lindgren, 2001; Okano et al., 2004; Cavagnaro et al., 2008; Di 371 et al., 2010). We therefore predicted an increase in AOB abundance and gene expression following 
372 the application of side-dressed nitrogen fertilizer. Ammonia oxidizing archaea, conversely, do not 373 typically increase in abundance after fertilizer $\mathrm{N}$ application. We hypothesized that AOA 374 abundance would remain similar or decrease on June 30 relative to May 3 pre-fertilization levels. 375 Indeed, AOA levels did not change from May 3 to June 30, after fertilization. While bacterial 376 amoA gene abundance was not significantly different between these time points either, AOB were 377 enriched on June 30 relative to total bacteria. This was reflected in a marginally greater AOB: total 378 bacteria ratio Post-Fertilization (June 30) than Pre-Tillage (May 3). Accordingly, inorganic N soil 379 levels were highest at the June 30 sampling date, which followed N side-dressing. Di et al. (2010) 380 found AOB to grow substantially after addition of a urine-N substrate in a grassland soil, whereas AOA grew solely in soils that did not receive substrate. In a microcosm study, Verhamme et al. 382 (2011) concluded that AOA growth was not strongly correlated to different rates of ammonia 383 oxidation; AOB exhibited the dominant response to high soil ammonium levels. Additionally, 384 seasonal changes in soil moisture and ambient air temperature likely had an influence on the 385 populations.

Given that the side-dressed $\mathrm{N}$ fertilizer applied at our site contained a substantial portion 387 of both urea and ammonium, we expected a response from AOB. Relative to total bacteria, we 388 observed a marginal increase in AOB abundance. This very well could be explained by enhanced 389 substrate availability and preferential growth conditions for ammonia oxidizing bacteria over their 390 archaeal counterparts. The effect of changing soil moisture and temperature with the progression 391 of the growing season stands as a potential confounding factor when considering AOB abundance 392 alone. Importantly, however, bacterial amoA gene abundance followed the seasonal pattern of $393 \mathrm{AOA}$ and total bacterial and archaeal communities at all time points except that date immediately 394 following the application of inorganic $\mathrm{N}$ fertilizer. Overall, our data suggest that AOB, not AOA, 
395 were the dominant ammonia oxidizing microorganisms in these cropping systems, particularly

396 following fertilizer $\mathrm{N}$ input.

397 Conclusions

398 The effects of 30-years of crop rotation and tillage on AO abundance and gene expression 399 supports the notion that AOB are functionally more important than AOA in neutral $\mathrm{pH}$, high-input 400 agricultural soils. Interestingly, despite high abundance of AOA, we did not detect archaeal amoA 401 gene expression. Throughout the season, we found that tillage influenced archaeal, but not 402 bacterial populations, no-till plots showed a pattern of increased total archaeal and AOA 403 abundance relative to conventional tillage. Distributions of AOB and AOA differed by depth, to 404 our knowledge, we are the first to show accentuated differences in AOB abundance and 405 transcriptional activity along a soil depth profile under long-term no-till versus conventional tillage 406 management. Finally, we anticipated a pronounced increase in AOB abundance and transcriptional 407 activity following an in-season application of inorganic nitrogen. Although this was not the case, 408 comparison with seasonal changes in total archaeal and bacterial abundance suggest that AOB and 409 AOA populations responded differently to nitrogen application.

\section{Acknowledgements}

411 The authors thank Karen Thompson for assistance with sample collection and Dr. Stephen Bowley 412 for assistance with statistical analysis of data. The project with funded in part by the Ontario 413 Ministry of Agriculture and Rural Affairs Highly Qualified Personnel Scholarship Program. 


\section{References}

416

417

418

419

420

421

422

423

424

425

426

427

428

429

430

431

432

433

434

435

436

437

438

439

440

441

442

443

444

445

446
Adair, K.L., and E. Schwartz. 2008. Evidence that ammonia-oxidizing archaea are more abundant than ammonia-oxidizing bacteria in semiarid soils of Northern Arizona, USA. Microb Ecol. 56(3):420-426. doi:10.1007/s00248-007-9360-9

Cavagnaro, T.R., L.E. Jackson, K. Hristova, and K.M. Scow. 2008. Short-term population dynamics of ammonia oxidizing bacteria in an agricultural soil. Appl. Soil Ecol. 40(1):1318. doi:10.1016/j.apsoil.2008.02.006

CSSC, 1998. The Canadian System of Soil Classification, third ed. CSSC.

Davis, A.S., J.D. Hill, C.A. Chase, A.M. Johanns, and M. Liebman. 2012. Increasing Cropping System Diversity Balances Productivity, Profitability and Environmental Health. PLoS ONE 7(10):1-8. doi:10.1371/journal.pone.0047149

De Quadros, P.D., K. Zhalnina, A. Davis-Richardson, J.R. Fagen, J. Drew, C. Bayer, F.A.O. Camargo, and E.W. Triplett. 2012. The effect of tillage system and crop rotation on soil microbial diversity and composition in a subtropical acrisol. Diversity 4(4):375-395. doi:10.3390/d4040375

Di, H.J., K.C. Cameron, J.P. Shen, C.S. Winefield, M. O'Callaghan, S. Bowatte, and J.Z. He. 2009. Nitrification driven by bacteria and not archaea in nitrogen-rich grassland soils. Nat. Geosci. 2:621-624. doi:10.1038/ngeo613

Di, H.J., K.C. Cameron, J.P. Shen, C.S. Winefield, M. O'Callaghan, S. Bowatte, and J.Z. He. 2010. Ammonia-oxidizing bacteria and archaea grow under contrasting soil nitrogen conditions. FEMS Microbiol. Ecol. 72(3):386-394.doi:10.1111/j.1574-6941.2010.00861.x

Dick, R.P. 1992. A review: long-term effects of agricultural systems on soil biochemical and microbial parameters. Agr. Ecosyst. Environ. 40(1-4):25-36. doi:10.1016/01678809(92)90081-L

Dimassi, B., J.P. Cohan, J. Labreuche, and B. Mary. 2013. Changes in soil carbon and nitrogen following tillage conversion in a long-term experiment in Northern France. Agr. Ecosyst. Environ. 169:12-20. doi:10.1016/j.agee.2013.01.012

Drury, C.F., R.P. Voroney, and E.G. Beauchamp. 1991. Availability of $\mathrm{NH}_{4}{ }^{+}-\mathrm{N}$ to microorganisms and the soil internal N cycle. Soil Biol. Biochem. 23(2):165-169

Edwards, J.H., C.W. Wood, D.L. Thurlow, and M.E. Ruf. 1992. Tillage and Crop Rotation Effects on fertility status of a Hapludult soil. Soil Sci. Soc. Am. J. 56(5):1577-1582. doi:10.2136/sssaj1992.03615995005600050040x 
Fierer, N., J. Jackson, R. Vilgalys, and R.B. Jackson. 2005. Assessment of soil microbial community structure by use of taxon-specific quantitative PCR assays. Appl. Environ. Microbiol. 71(7):4117-4120. doi:10.1128/AEM.71.7.4117

Gál, A., T.J. Vyn, E. Michéli, E.J. Kladivko, and W.W. McFee. 2007. Soil carbon and nitrogen accumulation with long-term no-till versus moldboard plowing overestimated with tilledzone sampling depths. Soil Till. Res. 96(1-2):42-51. doi:10.1016/j.still.2007.02.007

Gaudin, A., S. Westra, C. Loucks, K. Janovicek, R. Martin, and W. Deen. 2013. Improving Resilience of Northern Field Crop Systems Using Inter-Seeded Red Clover: A Review. Agron. 3(1):148-180. doi:10.3390/agronomy3010148

Gaudin, A., T.N. Tolhurst, A.P. Ker, K. Janovicek, C. Tortora, R.C. Martin, W. Deen. 2015. Increasing crop diversity mitigates weather variations and improves yield stability. PLoS ONE 10(2):e0113261. doi:10.1371/journal.pone.0113261

Glaser, K., Hackl, E., Inselsbacher, E., Strauss, J., Wanek, W., Zechmeister-Boltenstern, S., Sessitsch, A., 2010. Dynamics of ammonia-oxidizing communities in barley-planted bulk soil and rhizosphere following nitrate and ammonium fertilizer amendment. FEMS Microbiol. Ecol. 74, 575-591.

Gubry-Rangin, C., G.W. Nicol, and J.I. Prosser. 2010. Archaea rather than bacteria control nitrification in two agricultural acidic soils. FEMS Microbiol. Ecol. 74(3):566-574. doi:10.1111/j.1574-6941.2010.00971.x

Hatzenpichler, R. 2012. Diversity, physiology, and niche differentiation of ammonia-oxidizing archaea. Appl. Environ. Microbiol. 78(21):7501-7510. doi:10.1128/AEM.01960-12

He, J.Z., J.P. Shen, L.M. Zhang, Y.G. Zhu, Y.M. Zheng, M.G. Xu, and H. Di. 2007. Quantitative analyses of the abundance and composition of ammonia-oxidizing bacteria and ammoniaoxidizing archaea of a Chinese upland red soil under long-term fertilization practices. Environ. Microbiol. 9(9):2364-2374. doi:10.1111/j.1462-2920.2007.01358.x

Hermansson, A., and P. Lindgren. 2001. Quantification of Ammonia-Oxidizing Bacteria in Arable Soil by Real-Time PCR Quantification of Ammonia-Oxidizing Bacteria in Arable Soil by Real-Time PCR. Appl. Environ. Microbiol. 67(2):972-976. doi: 10.1128/AEM.67.2.972

Jayasundara, S., C. Wagner-Riddle, G. Parkin, P. Von Bertoldi, J. Warland, B. Kay, and P. Voroney. 2007. Minimizing nitrogen losses from a corn-soybean-winter wheat rotation with best management practices. Nutr. Cycl. Agroecosys. 79(2):141-159. doi:10.1007/s10705007-9103-9

Jia, Z., and R. Conrad. 2009. Bacteria rather than Archaea dominate microbial ammonia oxidation in an agricultural soil. Environ. Microbiol.11(7):1658-1671. doi:10.1111/j.14622920.2009.01891.x 
Kemnitz, D., S. Kolb, and R. Conrad. 2007. High abundance of Crenarchaeota in a temperate acidic forest soil. FEMS Microbiol. Ecol. 60(3):442-448. doi:10.1111/j.15746941.2007.00310.x

Kladivko, E.J. 2001. Tillage systems and soil ecology. Soil Till. Res. 61(1-2):61-76. doi:10.1016/S0167-1987(01)00179-9

Kreader, C. 1996. Relief of amplification inhibition in PCR with bovine serum albumin or T4 gene 32 protein. Appl. Environ. Microbiol. 62:1102-1106.

Légère, A., F.C. Stevenson, and A. Vanasse. 2011. Short Communication: A corn test crop confirms beneficial effects of crop rotation in three tillage systems. Can J Plant Sci. 91(5): 943-946. doi:10.4141/cjps2011-040

Leininger, S., T. Urich, M. Schloter, L. Schwark, J. Qi, G.W. Nicol, J.I. Prosser, S.C. Schuster, and C. Schleper. 2006. Archaea predominate among ammonia-oxidizing prokaryotes in soils. Nature 442(7104):806-809. doi:10.1038/nature04983

Levičnik-Höfferle, Š., G.W. Nicol, L. Ausec, I. Mandić-Mulec, and J.I. Prosser. 2012. Stimulation of thaumarchaeal ammonia oxidation by ammonia derived from organic nitrogen but not added inorganic nitrogen. FEMS Microbiol. Ecol. 80(1):114-123. doi:10.1111/j.1574-6941.2011.01275.x

Martens-Habbena, W., P.M. Berube, H. Urakawa, J.R. de la Torre, and D.A. Stahl. 2009. Ammonia oxidation kinetics determine niche separation of nitrifying Archaea and Bacteria. Nature. 461:976-979. doi:10.1038/nature08465

Moore, J. M., S. Klose, and M.A. Tabatabai. 2000. Soil microbial biomass carbon and nitrogen as affected by cropping systems. Biol. Fert. Soils 31(3-4):200-210. doi:10.1007/s003740050646

Munkholm, L. J., R.J. Heck, and B. Deen. 2013. Long-term rotation and tillage effects on soil structure and crop yield. Soil Till. Res. 127:85-91. doi:10.1016/j.still.2012.02.007

Németh, D., Wagner-Riddle, C., Dunfield, K., 2014. Abundance and gene expression in nitrifier and denitrifier communities associated with a field scale spring thaw $\mathrm{N}_{2} \mathrm{O}$ flux event. Soil Biol Biochem 73, 1-9.

Nicol, G. W., S. Leininger, C. Schleper, and J.I. Prosser. 2008. The influence of soil pH on the diversity, abundance and transcriptional activity of ammonia oxidizing archaea and bacteria. Environ. Microbiol. 10(11):2966-2978.doi:10.1111/j.1462-2920.2008.01701.x

Offre, P., J.I. Prosser, and G.W. Nicol. 2009. Growth of ammonia-oxidizing archaea in soil microcosms is inhibited by acetylene. FEMS Microbiol. Ecol. 70(1):99-108. doi:10.1111/j.1574-6941.2009.00725.x 
Okano, Y., K.R. Hristova, M. Christian, L.E. Jackson, R. F. Denison, B. Gebreyesus, D. Lebauer, K.M. Scow. 2004. Application of real-time PCR to study effects of ammonium on population size of ammonia-oxidizing bacteria in soil. Appl. Environ. Microbiol. 70(2):1008-1016. doi:10.1128/AEM.70.2.1008

Pratscher, J., M.G. Dumont, and R. Conrad. 2011. Ammonia oxidation coupled to CO2 fixation by archaea and bacteria in an agricultural soil. P. Natl. Acad. Sci. USA 108(10):4170-4175. doi:10.1073/pnas.1010981108

Prosser, J. I., and G.W. Nicol. 2012. Archaeal and bacterial ammonia-oxidisers in soil: The quest for niche specialisation and differentiation. Trends Microbiol. 20(11):523-531. doi:10.1016/j.tim.2012.08.001

Raimbault, B.A., and T.J. Vyn. 1991. Crop rotation and tillage effects on corn growth and soil structural stability. Agron. J. 83(6):979-985.doi:10.2134/agronj1991.000219620083000600 $11 \mathrm{x}$

Rotthauwe, J.H., K.P. Witzel, and W. Liesack. 1997. The ammonia monooxygenase structural gene $a m o A$ as a functional marker: Molecular fine-scale analysis of natural ammoniaoxidizing populations. Appl. Environ. Microbiol. 63(12):4704-4712. doi:10.1128/AEM.NA

Schauss, K., A. Focks, S. Leininger, A. Kotzerke, H. Heuer, S. Thiele-Bruhn, S. Sharma, B.-M. Wilke, M. Matthies, K. Smalla, J.C. Munch, W. Amelung, M. Kaupenjohann, M. Schloter, and C. Schleper. 2009. Dynamics and functional relevance of ammonia-oxidizing archaea in two agricultural soils. Environ. Microbiol. 11(2):446-456. doi:10.1111/j.14622920.2008.01783.x

Schleper, C. 2010. Ammonia oxidation: different niches for bacteria and archaea? ISME J. 4(9):1092-1094.doi:10.1038/ismej.2010.111

Shen, J.P., L.M. Zhang, H.J. Di, and J.Z. He. 2012. A review of ammonia-oxidizing bacteria and archaea in Chinese soils. Front. Microbiol. 3:1-7. doi:10.3389/fmicb.2012.00296

Souza, R.C., M.E. Cantão, A.T.R. Vasconcelos, M.A. Nogueira, and M. Hungria. 2013. Soil metagenomics reveals differences under conventional and no-tillage with crop rotation or succession. Appl. Soil Ecol. 72:49-61. doi:10.1016/j.apsoil.2013.05.021

Stopnišek, N., C. Gubry-Rangin, Š. Höfferle, G.W. Nicol, I. Mandič-Mulec, and J.I. Prosser. 2010. Thaumarchaeal ammonia oxidation in an acidic forest peat soil is not influenced by ammonium amendment. Appl. Environ. Microbiol. 76(22):7626-7634. doi:10.1128/AEM.00595-10

Tourna, M., T.E. Freitag, G.W. Nicol, and J.I. Prosser. 2008. Growth, activity and temperature responses of ammonia-oxidizing archaea and bacteria in soil microcosms. Environ. Microbiol. 10(5):1357-1364. doi:10.1111/j.1462-2920.2007.01563.x 
Treusch, A. H., S. Leininger, A. Kietzin, S.C. Schuster, H.P. Klenk, and C. Schleper. 2005. Novel genes for nitrite reductase and Amo-related proteins indicate a role of uncultivated mesophilic crenarchaeota in nitrogen cycling. Environ. Microbiol. 7(12):19851995.doi:10.1111/j.1462-2920.2005.00906.x

Venter, J. C. et al. 2004. Environmental genome shotgun sequencing of the Sargasso Sea. Science. 304 (5667):66-74. doi:10.1126/science.1093857

Verhamme, D. T., J.I. Prosser, and G.W. Nicol. 2011. Ammonia concentration determines differential growth of ammonia-oxidising archaea and bacteria in soil microcosms. ISME J. 5(6):1067-1071. doi:10.1038/ismej.2010.191

Wagner-Riddle, C., Furon, A., McLaughlin, N., Lee, I., Barbeau, J., Jayasundara, S., Parkin, G., von Bertoldi, P., Warland, J., 2007. Intensive measurment of nitrous oxide emissions from a corn-soybean-wheat rotation under two contrasting managment systems over 5 years. Global Change Biology 13, 1722-1736.

Wardle, D.A. (1995). Impacts of disturbance on detritus food webs in agro-ecosystems of contrasting tillage and weed management practices. Adv. Ecol. Res. 26:105-185. doi.org/10.1016/S0065-2504(08)60065-3

Wessén, E., K. Nyberg, J.K. Jansson, and S. Hallin. 2010. Responses of bacterial and archaeal ammonia oxidizers to soil organic and fertilizer amendments under long-term management. Appl. Soil Ecol. 45(3):193-200. doi:10.1016/j.apsoil.2010.04.003

WRB, 2006. World Reference Base for Soil Resources 2006. Food and Agriculture Organization of United Nations, Rome.

Zeglin, L.H., A.E. Taylor, D.D. Myrold, and P.J. Bottomley. 2011. Bacterial and archaeal amoA gene distribution covaries with soil nitrification properties across a range of land uses. Environ. Microbiol. Rep. 3(6):717-726. doi:10.1111/j.1758-2229.2011.00290.x

Zhang, J., Z. Cai, W. Yang, T. Zhu, Y. Yu, X. Yan, and Z. Jia. 2012. Long-term field fertilization affects soil nitrogen transformations in a rice-wheat-rotation cropping system. J. Plant Nutr. Soil Sci. 175(6):939-946. doi:10.1002/jpln.201200149

Zhang, L.-M., H.-W. Hu, J.P. Shen, and J.-Z. He. 2012. Ammonia-oxidizing archaea have more important role than ammonia-oxidizing bacteria in ammonia oxidation of strongly acidic soils. ISME J. 6(5):1032-1045. doi:10.1038/ismej.2011.168

Zibilske, L.M., J.M. Bradford, and J.R. Smart. 2002. Conservation tillage induced changes in organic carbon, total nitrogen and available phosphorus in a semi-arid alkaline subtropical soil. Soil Till. Res. 66(2):153-163 doi:10.1016/S0167-1987(02)00023-5 
Figure Captions

588 Figure 1. Mean number of copies of a) the bacterial amoA gene, b) the archaeal amoA gene, and 589 c) bacterial amoA transcripts per gram of dry soil under continuous corn (CC) and corn-corn-soy590 wheat-red clover (RC) rotations. Data averaged across tillage types (no-till and conventional 591 tillage) and depth increments $(0-5 \mathrm{~cm}, 5-15 \mathrm{~cm}$, and $15-30 \mathrm{~cm})$. The same letters above bars within 592 each graph represent a non-statistically significant difference $(\mathrm{P}<0.05)$ in mean copy number 593 between crop rotation treatments. Statistically significant difference $(\mathrm{P}<0.1)$ is indicated by *. 594 Bars represent standard error of the mean $(n=4)$.

595 Figure 2. Mean number of copies of a) the bacterial amoA gene, b) the archaeal amoA gene and 596 c) bacterial amoA transcripts, per gram of dry soil for no-till and conventional tillage sub597 treatments at 0-5, 5-15, and $15-30 \mathrm{~cm}$ depth increments. Data averaged across rotation treatments 598 and sampling dates at each depth increment. The same lower case letters beside bars within the 599 no-till sub-treatment and same upper case letters within the conventional tillage sub-treatment 600 represent non-statistically significant $(\mathrm{P}<0.05)$ differences in mean copy number amongst depth 601 increments. Bars represent standard error of the mean $(n=4)$.

602 Figure 3. Mean number of copies for a) the bacterial $16 \mathrm{~S}$, b) archaeal $16 \mathrm{~S}$, c) bacterial amoA, and 603 d) archaeal $a m o A$ genes per gram of dry soil by sampling date, under no-till (NT) and conventional 604 tillage (CT) sub-treatments. Data averaged across rotation treatments and depth increments (0-5 $605 \mathrm{~cm}, 5-15 \mathrm{~cm}$, and 15-30 cm). Time-points represent pre-spring tillage and planting (May 3), post606 nitrogen side-dress application (June 30), pre-plowing (October 12), and post-plowing (November 607 23). Bars represent standard error of the mean $(n=4)$. The same letters between time-points 608 represent non-statistically significant $(\mathrm{P}<0.05)$ differences in mean gene abundance (no-till and 609 conventional tillage pooled). Regression lines provided only to demonstrate trends of data over 610 time. 

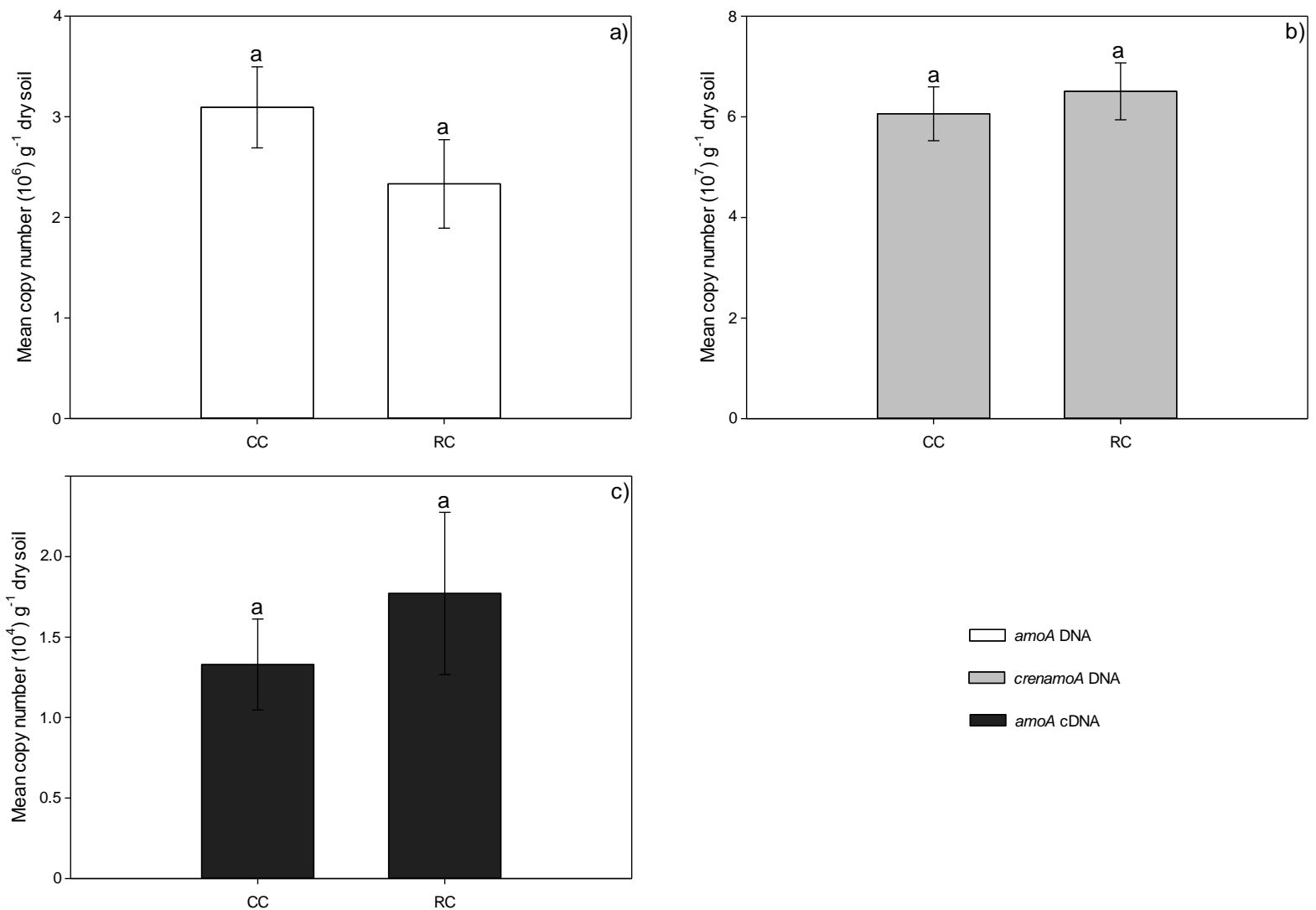

612

\section{$613 \quad$ Fig 1}

614 

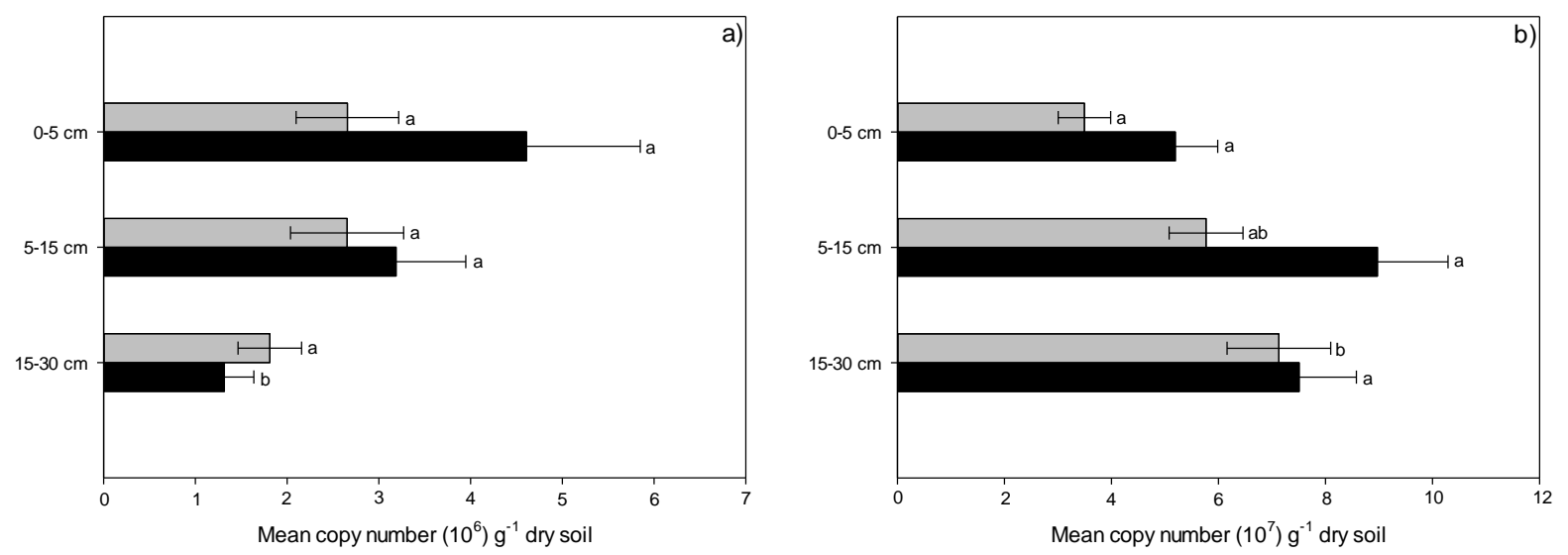

615

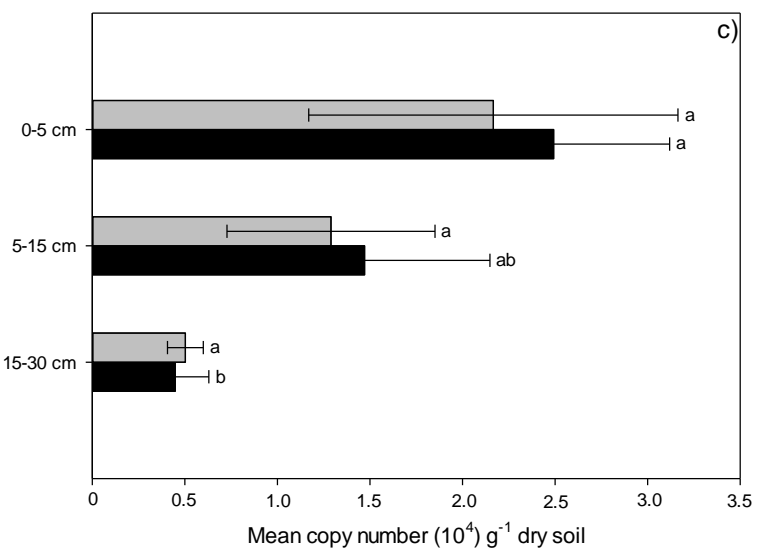

No-till

$\square$ Conventional tillage

\section{$616 \quad$ Fig 2}

617 

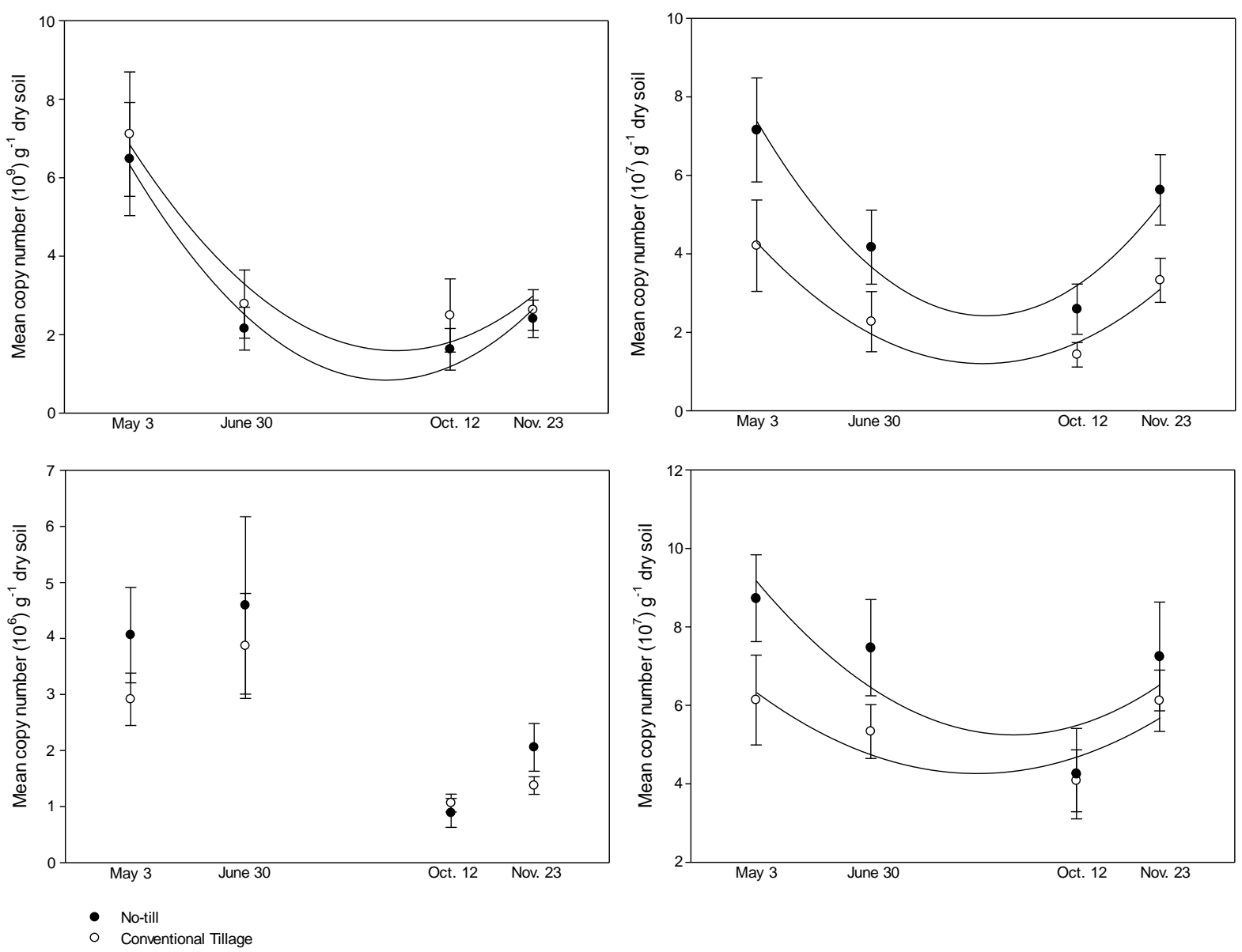

618

$619 \quad$ Fig 3

620

621

622

623

624

625

626

627

628 
Table S1. Mean soil pH (n=4) under main plot rotation treatments, 2010.

\begin{tabular}{ll}
\hline Crop rotation & SoilєßB \\
\hline Continuous corn & 7.51 \\
\hline Corn-Corn-Soybean-Winter Wheat (Red Clover) & 7.48 \\
\hline
\end{tabular}

631

632 Table S2. Soil moisture and ambient surface air temperature on sampling dates.

\begin{tabular}{lll}
\hline Sampling Date & Soil Moisture $(\%)$ & Temperature $\left({ }^{\circ} \mathrm{C}\right)$ \\
\hline Pre-tillage (May 3) & 22.1 & 18.1 \\
Post-fertilization (June 30) & 16.4 & 15.2 \\
Pre-plowing (October 12) & 18.5 & 8.9 \\
Post-plowing (November 23) & 16.4 & 4.8 \\
\hline
\end{tabular}

633

634

635 Table S3. Sequences, target genes, and associated citations for primer pairs used.

\begin{tabular}{|c|c|c|c|}
\hline Primer & Sequence (5'-3') & Target & Citation \\
\hline amoA-1F & GGGGTTTCTACTGGTGGT & \multirow{2}{*}{$\begin{array}{l}\text { Ammonia } \\
\text { monooxygenase gene }\end{array}$} & \multirow[t]{2}{*}{ Rotthauwe et al., 1997} \\
\hline amoA-2R & CCCCTCKGSAAAGCCTTCTTC & & \\
\hline crenamoA-23F & ATGGTCGGCTWAGACG & \multirow{2}{*}{$\begin{array}{l}\text { Ammonia } \\
\text { monooxygenase gene }\end{array}$} & \multirow[t]{2}{*}{ Tourna et al., 2008} \\
\hline crenamoA-616R & GCCATCCATCTGTATGTCCA & & \\
\hline bac16S-338F & ACTCCTACGGGAGGCAGCAG & \multirow{2}{*}{$\begin{array}{l}\text { 16S small ribosomal } \\
\text { gene }\end{array}$} & \multirow[t]{2}{*}{ Fierer et al., 2005} \\
\hline bac16S-518R & ATTACCGCGGCTGCTGG & & \\
\hline $\operatorname{arch} 16 S-364 \mathrm{~F}$ & CGGGGYGCASCAGGCGCGAA & \multirow{2}{*}{$\begin{array}{l}\text { 16S small ribosomal } \\
\text { gene }\end{array}$} & \multirow[t]{2}{*}{ Kemnitz et al., 2007} \\
\hline $\operatorname{arch16S-934R~}$ & GTGCTCCCCCGCCAATTCCT & & \\
\hline
\end{tabular}


Table S4. Long term rotation, tillage, sampling date and depth effects on bacterial and archaea amoA and $16 S$ gene abundance, as well

\begin{tabular}{|c|c|c|c|c|c|c|c|c|}
\hline & $\mathrm{df}$ & $\begin{array}{l}\text { Bacterial } \\
\text { amoA gene } \\
\text { abundance }\end{array}$ & $\begin{array}{l}\text { Archaeal } \\
\text { amoA gene } \\
\text { abundance }\end{array}$ & $\begin{array}{l}\text { Bacterial } 16 S \\
\text { gene } \\
\text { abundance }\end{array}$ & $\begin{array}{l}\text { Archaeal } 16 S \\
\text { gene } \\
\text { abundance }\end{array}$ & $\begin{array}{l}\text { Bacterial } \\
\text { amoA } \\
\text { transcript } \\
\text { abundance* }\end{array}$ & $\begin{array}{l}\text { Bacterial } \\
\text { amoA: } 16 S \\
\text { gene } \\
\text { abundance }\end{array}$ & $\begin{array}{l}\text { Archaeal } \\
\text { amoA: } 16 S \\
\text { gene } \\
\text { abundance }\end{array}$ \\
\hline & & $\operatorname{Pr}(>\mathrm{F})$ & $\operatorname{Pr}(>\mathrm{F})$ & $\operatorname{Pr}(>\mathrm{F})$ & $\operatorname{Pr}(>\mathrm{F})$ & $\operatorname{Pr}(>\mathrm{F})$ & $\operatorname{Pr}(>\mathrm{F})$ & $\operatorname{Pr}(>\mathrm{F})$ \\
\hline Rotation & 1 & 0.0591 & 0.0723 & 0.1242 & 0.6444 & 0.4780 & 0.0285 & 0.5445 \\
\hline Tillage & 1 & 0.2412 & 0.2370 & 0.1702 & 0.1000 & 0.0467 & 0.2262 & 0.2685 \\
\hline Date & 3 & $<0.0001$ & 0.1455 & $<0.0001$ & 0.0007 & 0.2628 & 0.0115 & 0.0132 \\
\hline Depth & 2 & $<0.0001$ & 0.0215 & 0.0082 & 0.0050 & 0.0211 & 0.0112 & 0.0010 \\
\hline Rotation $\times$ Tillage & 1 & 0.3514 & 0.3776 & 0.0445 & 0.5243 & 0.1357 & 0.5441 & 0.1158 \\
\hline Rotation $\times$ Date & 3 & 0.6483 & 0.0590 & 0.1351 & 0.1871 & 0.1201 & 0.8914 & 0.8246 \\
\hline Rotation $\times$ Depth & 2 & 0.4569 & 0.1095 & 0.3651 & 0.1330 & 0.6110 & 0.9124 & 0.7705 \\
\hline Tillage $\times$ Date & 2 & 0.2093 & 0.3016 & 0.2296 & 0.4864 & 0.6281 & 0.7594 & 0.9201 \\
\hline Date $\times$ Depth & 6 & 0.1072 & 0.7356 & 0.0007 & 0.0386 & 0.0132 & 0.9875 & 0.1788 \\
\hline Depth $\times$ Tillage & 2 & 0.0011 & 0.1904 & 0.2292 & 0.4078 & 0.4404 & 0.0251 & 0.4816 \\
\hline Rotation $\times$ Tillage $\times$ Date & 3 & 0.5883 & 0.5221 & 0.5027 & 0.1890 & 0.4013 & 0.7382 & 0.4417 \\
\hline Rotation $\times$ Date $\times$ Depth & 6 & 0.1344 & 0.1249 & 0.0128 & 0.5046 & 0.2751 & 0.5707 & 0.7109 \\
\hline Rotation $\times$ Depth $\times$ Tillage & 2 & 0.3897 & 0.0293 & 0.5809 & 0.5436 & 0.5223 & 0.1671 & 0.0891 \\
\hline Tillage $\times$ Depth $\times$ Date & 6 & 0.0021 & 0.4600 & 0.0077 & 0.1946 & $\mathrm{n} / \mathrm{a}$ & 0.0425 & 0.5833 \\
\hline Rotation $\times$ Tillage $\times$ Date $\times$ Depth & 6 & 0.6356 & 0.0067 & 0.0633 & 0.5578 & $\mathrm{n} / \mathrm{a}$ & 0.0719 & 0.4615 \\
\hline
\end{tabular}


644 Table S5. Soil ammonium- and nitrate-nitrogen values $\left(\mathrm{mg} \mathrm{kg}^{-1}\right.$ dry soil) averaged across rotation treatments, tillage sub-treatments, 645 and across depth increments at each sampling date. Different lower case letters represent a statistically significant $(P<0.05)$ difference between sampling dates. Standard error of the mean is provided after \pm symbol.

\begin{tabular}{lll}
\hline Sampling Date & $\mathbf{N H}_{\mathbf{4}}^{+}\left(\mathbf{m g ~ k g}^{-\mathbf{1}} \mathbf{d r y}\right.$ soil $)$ & $\mathbf{N O}_{\mathbf{3}} \mathbf{~} \mathbf{m g ~ k g}^{-\mathbf{1}} \mathbf{\text { dry soil } )}$ \\
\hline May 3 & $2.64 \pm 0.54 \mathrm{a}$ & $6.70 \pm 1.02 \mathrm{~b}$ \\
June 30 & $5.70 \pm 1.35 \mathrm{a}$ & $14.49 \pm 2.36 \mathrm{a}$ \\
October 12 & $2.03 \pm 0.43 \mathrm{a}$ & $5.04 \pm 0.56 \mathrm{~b}$ \\
November 23 & $2.35 \pm 0.41 \mathrm{a}$ & $3.84 \pm 0.43 \mathrm{c}$ \\
\hline
\end{tabular}

647 